\title{
THE 2019 POLICY CHANGES TO CANADA'S PARENT AND GRANDPARENT SPONSORSHIP PROGRAM
}

\author{
by \\ Stephanie Pietrantonio, BA, McGill University, 2013 \\ A Major Research Paper \\ presented to Ryerson University \\ in partial fulfillment of the \\ requirements for the degree of \\ Master of Arts \\ in the program of \\ Immigration and Settlement Studies
}

Toronto, Ontario, Canada, 2019

(C) Stephanie Pietrantonio, 2019 


\section{AUTHOR'S DECLARATION FOR ELECTRONIC SUBMISSION OF A MAJOR RESEARCH PAPER (MRP)}

I hereby declare that I am the sole author of this MRP. This is a true copy of the MRP, including any required final revisions. I authorize Ryerson University to lend this MRP to other institutions or individuals for the purpose of scholarly research. I further authorize Ryerson University to reproduce this MRP by photocopying or by other means, in total or in part, at the request of other institutions or individuals for the purpose of scholarly research. I understand that my MRP may be made electronically available to the public. 


\title{
THE 2019 POLICY CHANGES TO CANADA'S PARENT AND GRANDPARENT SPONSORSHIP PROGRAM
}

\author{
Stephanie Pietrantonio \\ Master of Arts 2019 \\ Immigration and Settlement Studies \\ Ryerson University
}

\begin{abstract}
On January 28th, 2019, Immigration, Refugee and Citizenship Canada (IRCC) opened the most recent application form for the Parent and Grandparent Sponsorship form (PGP). After 11 minutes, the 27,000 spots allocated for the "Interest to Sponsor" (ITS) forms had been filled and IRCC announced that the application had closed (Harris, 2019). This study will review the literature on the evolution of family reunification in Canadian immigration policies and will include a critical analysis of the 2019 PGP sponsorship program. It will explore the changes to the online system for the 2019 PGP application process, outlining its failure to provide an equitable opportunity for those wishing to reunite with their family members in Canada. By placing the most recent experience with the 2019 PGP application process in the context of the history of family reunification policies in Canada, this study will identify the continuities and changes in the ideologies guiding policy shifts and will highlight what is and isn't working in the current policy.
\end{abstract}

Keywords: Canadian immigration policy, family reunification, family sponsorship, parent and grandparent sponsorship program 


\section{ACKNOWLEDGEMENTS}

I would like to acknowledge my professors and classmates, whose support and inspiration guided me throughout the MA program. I would like to thank my supervisor, Dr. Sepali Guruge, for supporting me throughout the process of writing my MRP. I also want to express my appreciation for my second reader, Dr. Myer Siemiatycki, for whose time, effort and positivity I am truly grateful. Lastly, I would like to thank my parents and grandparents for their courage and bravery throughout their immigration and settlement experience in Canada. Without the generous family sponsorship policies of the 1960's that allowed the sponsorship of siblings, their experience as Southern-Italians would have been very different. 


\section{LIST OF FIGURES}

Figure 1: Admission categories by year of immigration, Canada, 1980 to $2016 \ldots \ldots \ldots \ldots \ldots . . . . .18$

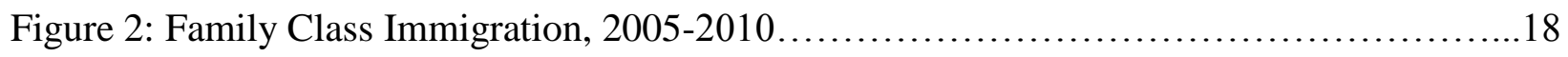

Figure 3: Top source regions for family-class immigration to Canada.....................21 


\section{TABLE OF CONTENTS}

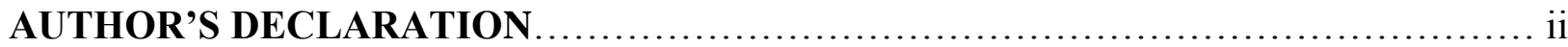

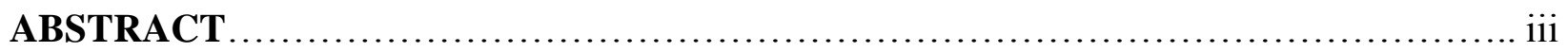

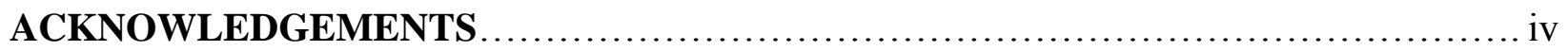

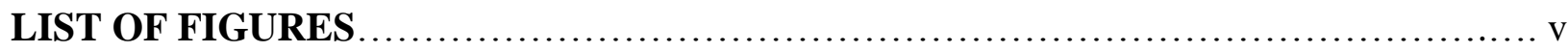

CHAPTER 1: INTRODUCTION ............................................. 1

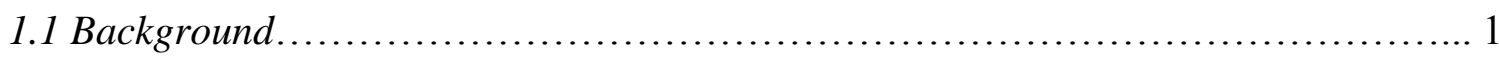

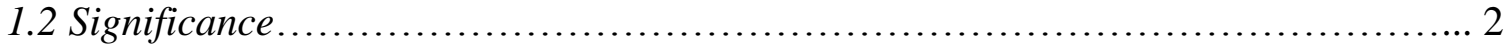

1.3 Research Question....................................................... 3

CHAPTER 2: THEORETICAL FRAMEWORK $\ldots \ldots \ldots \ldots \ldots \ldots \ldots \ldots \ldots \ldots \ldots \ldots \ldots \ldots . \ldots \ldots$

CHAPTER 3: METHODOLOGY ................................................ 6

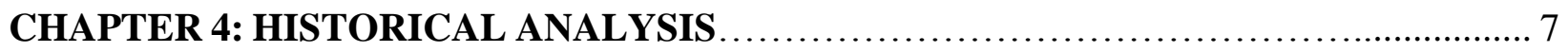

4.1 Family Reunification in Canadian Immigration Policies........................... 7

4.2 Parent and Grandparent (PGP) Sponsorship Program........................ 10

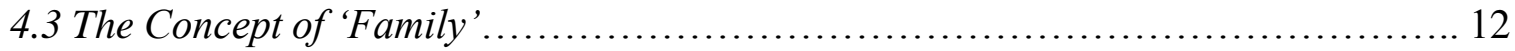

4.4 The Value of Parents and Grandparents.................................. 15

4.5 Neoliberal Shifts in Family Reunification \& the PGP Sponsorship Program......... 16

CHAPTER 5: CRITICAL ANALYSIS ......................................... 22

5.2 2018 Policy Changes and the 2019 PGP Sponsorship Application Process........... 22

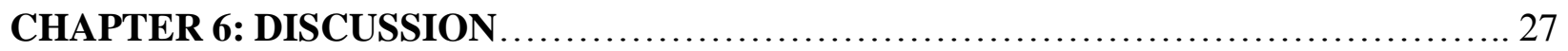

CHAPTER 7: CONCLUSION AND IMPLICATIONS............................. 29

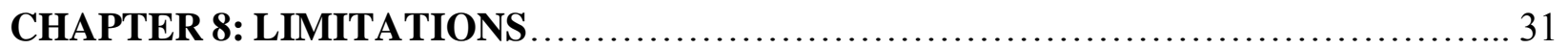

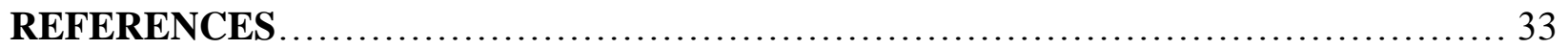




\section{CHAPTER 1: INTRODUCTION}

\subsection{Background}

Canada's current immigration policy provides Canadian citizens and permanent residents (PR) with the opportunity to sponsor their parents or grandparents through the "Parent and Grandparent Program" (PGP) sponsorship program. While this policy suggests the government's support for family reunification, the eligibility requirements and limited application availability indicate a program that is restrictive and inaccessible for many families that are separated across borders and want to reunite with their family members in Canada (Bragg \& Wong, 2016). The inaccessibility of the PGP sponsorship program was apparent in the most recent online application process that opened with the "Interest to Sponsor" (ITS) form on January $28^{\text {th }}, 2019$ (IRCC, 2019). The ITS form is the first step in the PGP sponsorship process and must be accepted online before an individual is invited to submit a complete application for the PGP sponsorship program. After 11 minutes, the 27,000 spots allocated for ITS forms had been filled IRCC announced that the application window for 2019 had closed (Harris, 2019). Immigration, Refugees and Citizenship Canada (IRCC) announced that the system had been vigorously tested to ensure that there wouldn't be any technological glitches when the application went live on the Internet, therefore signifying the government's expectation of a high applicant turnout (IRCC, 2019). This expectation was correct; 100,000 individuals accessed the online ITS form and the quota for family sponsorship was quickly reached on a first-come, first-served system (Harris, 2019).

The limited number of application spots meant that applicants who met the requirements for sponsorship, and who had prepared the necessary information and documentation, were not granted the opportunity to submit an ITS form and were therefore left out of the PGP 
sponsorship program for 2019. The high demand for family sponsorship indicates the importance of family reunification for Canadian citizens and permanent residents (PR) however, the most recent experience with the ITS form, and the speed at which available spots filled up, demonstrates a process that is not sufficient to address the demand and need for families to reunite. This discrepancy highlights a social issue that is not addressed through a program that has continually undergone policy changes dependent upon the governing party in power, as well as an application system that has faced continual public criticism and frustration (Keung, 2019).

This frustration stems from the government's failure to acknowledge the importance of family reunification in immigration policy and, instead, its prioritization of economic class immigrants in federal immigration policies. There is a fundamental injustice in this prioritization as it leads to the ongoing separation of families across borders and it signifies a lack of recognition in the role that families play in the emotional, social and economic well-being of immigrants. Limiting the number of people who can be sponsored through annual application quotas and strict requirements for the program; such regulations leave the most vulnerable families ineligible to apply due to a variety of factors, the most prominent of these factors being household income level (Bragg \& Wong, 2016).

\subsection{Significance}

Currently, the research surrounding family reunification and sponsorship examines the evolution of the policy; this study aims to critically analyze the most recent 2019 application process to identify continuities and the differences in the ideologies guiding family reunification policies. The 2019 PGP Sponsorship Program application process highlights both a failure in the current policy and the online process to address the social issue of family separation. By 
exploring the 2019 policy, this MRP will identify some of the differences in the new first-comefirst-served ITS application form and how its implementation in immigration policy represents a neoliberal shift in family reunification.

\subsection{Research Question}

The guiding research question for this study is: what are the changes to the 2019 PGP Sponsorship Program application process? By exploring the 2019 PGP application process, this MRP will identify some of the changes to the new system and what the changes may signify for the future of the sponsorship of parents and grandparents in Canadian immigration policy.

\section{CHAPTER 2: THEORETICAL FRAMEWORK}

Neoliberalism has increasingly influenced Canadian immigration policy; it has had an impact on how family reunification is viewed and valued at the federal level (Bragg \& Wong, 2016, p.46). Neoliberalism is helpful in understanding the decision-making in immigration programs because it highlights the economic logic that guides policy-making in a capitalist society; it also emphasizes the prioritization of the economic contribution of individuals as the

most important factor in decision-making (Roberts \& Mandani, 2010, p.251). Neoliberalism, and its emphasis on economic output, provides the theoretical background to understand how family reunification is undervalued in the current immigration policy. In a neoliberal society, individuals are expected to be "self-reliant" and "self-sufficient" and, therefore, the understanding that society is responsible for the well-being of its citizens diminishes, along with the reduction of the welfare state (Arat-Koc, 1999, p.34). The notion of individual responsibility in a neoliberal society is helpful in understanding how parents and grandparents are viewed by 
policymakers and how this view is reflected in the application process of the 2019 PGP Sponsorship Program.

Furthermore, the specific changes to the 2019 family sponsorship policy and application process are understood through human-capital theory which emphasizes skills and education as the factors that determine the economic output of an individual. This determines what kind of individual would be a "desirable" immigrant (Bragg \& Wong, 2016, p. 29). Neoliberalism and human-capital theory are connected in immigration policy through the way in which they influence and determine the type of individual that would be eligible to apply for the PGP, as well as the type of individual whose ITS form would have a higher chance of acceptance during the application process. Human-capital theory directly connects the value of an individual to their place in the labour market in that it argues that the more skills and education an individual has, the more likely they to succeed in the labour market and contribute to society (Bragg \& Wong, 2016, p.49). In a neoliberal society, in which an individual's value is connected to their human capital, the sponsorship of parents and grandparents is not prioritized in the federal immigration policies that favour individuals with the skills and education that could adapt to the labour market needs of the time (Arat-Koc, 1999, p.43). The influence of neoliberalism and human-capital theory is reflected in the limited availability of PGP sponsorship in comparison to the economic classes of immigration; it is also further emphasized in the eligibility requirements for the PGP sponsorship. IRCC's website clearly outlines the requirements to sponsor a family member, these requirements include a minimum income of $\$ 40,379$ to sponsor two people and a 20-year "length of undertaking," a period during which the applicant is financially responsible for the sponsored parent or grandparent (IRCC, 2019). 
Colonialism also plays a key role in the analysis of the 2019 PGP Sponsorship Program as it highlights the dominance of a Western worldview in both the policy itself and the online application process. This worldview determines how the concept of family is understood in the policy as well as the language requirements in the application form. The first step of sponsorship, the ITS form, is more accessible and easier to navigate for those who speak English or French fluently and understand the language and vocabulary used throughout the process. Considering that the 2019 application closed within 11 minutes and on a first-come, first-served basis, an interested applicant's knowledge of French or English is a crucial factor in the application process. Individuals who do not speak English or French as their first language may take more time to understand and fill out the ITS form and, therefore, less likely to be successful in a process in which time plays a crucial role. It is also important to acknowledge the role of colonialism in the overall understanding of the importance of parents and grandparents in immigration policy. How policymakers define the concept of "family" and who is included as "family" becomes an important factor in the interpretation of Canada's commitment to family reunification through sponsorship policies. The concept "family" is perceived differently in Western societies and is typically understood as the "nuclear family" of a couple and their children (Telegdi, 2006). This definition determines who is eligible for family sponsorship however, it fails to acknowledge that this is not the family model that is recognized in most societies, thus reflecting the dominance of Western values in family reunification policies (Telegdi, 2006).

The theoretical frameworks provided by neoliberalism, human-capital theory and colonialism are connected in the way that they influence immigration policy and how they determine the type of individual that is likely to have their application accepted in the PGP 
Sponsorship Program. Neoliberalism and human-capital theory fit together through their emphasis on market-oriented principles and the economic prioritization that guides immigration polices however, they do not capture the colonial influence in the ITS form and the PGP online application that benefits some groups and creates barriers for others through the dominance of the English or French language throughout the process. Thus, the integration of these three theories is helpful in analyzing the elements within the PGP sponsorship application process and the impact of the recent policy changes to the 2019 ITS form.

\section{CHAPTER 3: METHODOLOGY}

The purpose of this major research paper (MRP) is to present a historical analysis of the evolution of family reunification in immigration policy and a critical analysis of the 2019 PGP Sponsorship Program. This study will include a literature review of the history of family reunification in Canadian immigration policies and the influence of the ideologies that have guided decision-making. Since the admission of immigrants with relatives was officially recognized with the Immigration Act of 1910 (Li, 2017, p.4), this study will utilize peer-reviewed journal articles and dissertations that explore the history of Canadian immigration policy from 1910 onwards. The collection of literature includes a historical analysis of family reunification in Canada however, it will focus more on the policy shifts since the 1990's that reflected the growing influence of neoliberalism in Canadian immigration policy. The literature review is reflective of the discourse that critiques both the Liberal and Conservative governments from the 1990's onwards in order to address some of the bias that may be included in the work.

The study involves a critical analysis of the 2019 PGP Sponsorship Program and its online application process to identify the differences in the new system and to highlight some of the experiences of those who accessed the online ITS to reunite with their families in Canada. 
Since this is a recent event, this study will review the online literature available regarding the 2019 application process. The literature reviewed will include a combination of news releases and government statements leading up to the 2019 application opening and following the aftermath of the process. A review of the media coverage includes online articles from five news broadcasting sources publications across Canada. These sources were selected due to their consistent coverage of the recent application process and their inclusion of interviews with applicants, immigration lawyers and consultants in their publications. The analysis highlights content from major news sources such as the national public broadcaster, Canadian Broadcasting Corporation (CBC), as well as regional sources throughout the country, such as The Globe and Mail. The sources were selected in order to give different regional perspectives on the 2019 application process and to include different experiences with applicants across the country.

\section{CHAPTER 4: HISTORICAL ANALYSIS}

\subsection{Family Reunification in Immigration Policy}

There is a breadth of literature on the history of family reunification in Canada; this section will briefly cover this history to demonstrate how the perception of family reunification has evolved and the way that its evolution has been reflected in immigration policies. The concept of family reunification through immigration has existed in Canada since 1908 however, its definition and objectives have continued to evolve alongside changing government administrations and the ideologies that guided their immigration policies (DeShaw, 2006, p.10).

As mentioned, the first provision for admitting immigrants with relatives appeared in 1908 and, in 1910, the government specified that the types of individuals that could be eligible for family immigration were wives, children, parents, and siblings (DeShaw, 2006, p.10). From 
1910 until the 1950's, the individuals eligible for family sponsorship continually shifted in response to the economic needs of the time. This is evident when exploring the policies of the 1920's and 1930's; in the 1920's, unmarried children over the age of 18 were added to the group of eligible family members however, during the economic downturn of the Great Depression, only wives and children under the age of 18 were considered "core family members" (DeShaw, 2006, p.10). The expansion and restriction of those included in the family class is an early representation of the definition of "family" being connected to the economic needs of the time. While the economic benefit or "burden" of family sponsorship may not have been completely solidified from 1910 to 1950 , it is clear that the need for families to be together was not the primary factor in decision-making process surrounding family reunification (DeShaw, 2006, p.10)

A similar shift occurred during a time of labour shortages in post-World War Two years; in the 1940's, businesses and government officials recognized that an open immigration policy would be needed to fill employment gaps and support the economic growth in the industrial, construction and manufacturing sectors (Harney, 1998). Thus, in 1950, the family class was expanded to include any relative of any degree in 1950 (DeShaw, 2006, p.10). However, this expansion caused administrative problems and the individuals included in the eligible group fluctuated between 1950 and 1959 (DeShaw, 2006, p. 10). Then, in 1965, tensions between the prioritization of the labour market in immigration policy and the value of family reunification through immigration began to appear however, the possibility of the government placing restrictions on those included in the family class in favour of a policy centred around labour market needs faced strong public criticism that paused policy shifts (DeShaw, 2006, p.10). This tension resulted in the creation of two separate classes of family reunification; in 1967, there was 
the emergence of the "nominated relatives" category, which was restricted by labour-market requirements and the "sponsored dependents" category, which eventually became the "family" class in the 1976 Immigration Act (DeShaw, 2006, p.10).

The 1976 Immigration Act represented the first time that a formal immigration policy outlined support for family reunification; up until this point, the purpose of family reunification in Canada experienced continual shifts in response to labour market needs and it seemed that the objective of family sponsorship was closely tied its economic value (DeShaw, 2006). However, the 1976 Immigration Act, clarified that the objective of family reunification was "to facilitate the reunion in Canada of Canadian citizens and permanent residents with their close relatives from abroad" (DeShaw, 2006, p.10). Eventually, family class immigration grew to represent 40 to 50 per cent of total immigration to Canada in the 1970's and became the dominant method through which individuals entered the country (DeShaw, 2006).

Throughout the fluctuations in eligibility for family sponsorship from 1900's, it was clear that parents and grandparents were considered members of the 'core family unit' and were thus legitimate candidates for family reunification, this is exemplified by the 1974 Green Paper on Immigration, which stated "when Canada accepts immigrants, we consider ourselves duty-bound also to accept those close relatives who would normally be dependent on them in a society such as our own" (Chen, 2015, p.86). While this passage indicated a duty to support "close relatives," it also encouraged the view that parents and grandparents were simply viewed as "dependents" in the minds of policymakers. This quote also raises the question of who is considered a "close relative" in the eyes of Canadian policy makers. As will be discussed further, this the concept of "closeness" and the view that parents and grandparents are merely "dependents" started to 
become problematic as neoliberal ideologies became more dominant in immigration policy in the 1990's and into the 2000's.

\subsection{Parent and Grandparent (PGP) Sponsorship Program}

The literature surrounding the PGP Sponsorship Program focuses on the policy changes that emerged in the early 1990's that reflected a growing prioritization of economic class immigrants, as well as the challenges associated with application backlogs and long processing times for PGP applicants. As discussed in the above section, while the inclusion criteria for family sponsorship shifted throughout the 1900's, parents and grandparents were continually considered to be part of the 'family unit'. This section outlines how the legitimacy of parents and grandparents in family reunification was not widely questioned until the 1990's with the Liberal government's response to the economic downturn of the 1980's and the re-evaluation of the policies that determined the number of individuals in each immigration class (Neborak, 2013).

As mentioned, the debate surrounding immigration evolved in response to the economic climate of the country however, in the 1990's, the importance of the labour market in immigration policy became more apparent as policy makers became more concerned with improving the quality of the labour market (Neborak, 2013). This led to a review of the 1976 Immigration Act which eventually led to a report that further emphasized the necessity of immigrants being able to "adapt, prosper, and help Canada grow” (Neborak, 2013, p.10). Such wording indicated a growing concern for the "self-sufficiency" of immigrants entering Canada and is more easily understood through human-capital theory, which, in immigration policy, determines the value of an individual based on their contribution to Canadian society. As mentioned, throughout the 1990's, policy makers believed that what was best for the Canadian 
society was the expansion and improvement of the labour market. Therefore, the changes to the sponsorship of parents and grandparents throughout the 1990's were partially a result of a shift in prioritization to the human-capital that immigrants contributed through their connection to the labour market. This shift represented a key turning point in the PGP Sponsorship Program and the issues and criticisms that the program and its application process continue to face.

The Liberal government began placing restrictions on the sponsorship of elderly parents and grandparents and reduced the overall proportion of parents and grandparents in comparison to other Family Class immigrants (Chen, 2015). This resulted in the administrative delays and longer processing times that would lead to further restrictions and policy changes surrounding the PGP in 2012 with the Conservative government in power (Chen, 2015). However, as mentioned, it was the Liberal government that initiated the restrictions in the 1990's, justifying their actions by highlighting their support for the value of economic immigrants, whilst shifting who was included in their commitment to "reunite close family members" (Chen, 2015). For the first time, the "closeness" of parents and grandparents in regard to family reunification was questioned; Citizenship and Immigration Canada (CIC) represented this shift as instead ensuring that "spouses, partners, and dependent children" were processed on a priority basis (Chen, 2015).

The change in the 1990's is significant as it represented the beginning of the restrictions on the reunification of parents and grandparents in Canada and the change in perception of parents and grandparents. This change in perception was due to characteristics that would be considered as a burden as opposed to a contribution to the labour market, the most obvious characteristic being the age of sponsored parents and grandparents in comparison to economic class immigrants. The emphasis on characteristics such as age signified a growing perception of 
parents and grandparents as a liability as opposed to an important part of settlement and integration, as had been the case in the 1960's and 1970's.

\subsection{The Concept of 'Family'}

A dominant theme that emerges from the literature is the concept of 'family;' this section explores what this term means to Canadian policymakers, how it is defined in immigration policy, and how this definition can shift according to the economic climate and the priorities of the of the governing party. How policymakers choose to define 'family' is important as it determines who is included in the family unit and, thus, who is eligible for sponsorship. The literature emphasizes that a key part in understanding family reunification in Canada and the evolution on family sponsorship is understanding the concept of family and how policymakers view it through a neoliberal and colonial lens. It is evident that the family unit is perceived differently in Western societies; policymakers" narrow view of "family" and its presence in immigration policy reflects the dominance of Western values in family reunification program.

As highlighted above, family reunification policies shifted, as did the concept of family and the definition of who was considered to be part of the "family" in regard to immigration policy. The shifts in the inclusion and exclusion criteria for "family" changed as the make-up of Canada shifted and the ideologies guiding immigration policy began to favour economic principles. This is evident in the fact that individuals in the family class once included only wives and unmarried minors and then expanded to include any relative of any degree (DeShaw, 2006).

As the Canadian economy shifted, so did the concept of "family;" throughout the 1900's the range of relatives that could be sponsored was broad and was responsible for the chain 
migration during the post-World War Two years that changed the ethnic make-up of Canadian society (Aguiar, 2003). It is important to note the economic and racial biases that were connected to the concept of 'family' and who was included in this group. As more Southern Europeans entered Canada through the broad regulations of family sponsorship, it became evident that the inclusion criteria needed to change in order to restrict entry to those deemed "desirable" at the time (Chen, 2015). When the regulations surrounding country of origin in immigration policy were broadened to encourage an increase in immigration after the war, Southern Europeans were not the preferred immigrants due to their "not-quite-white skin" and "backward" culture that did not fit into the dominant Anglo-Saxon community (Aguiar, 2003). The increase in sponsored immigrants meant an increase in immigrants who would not have been eligible through the skilled immigrant program; this increase did not align with Canada's desire to build a skilled workforce, especially since sponsored immigrants were mostly from Italy, Portugal and Greece (Chen, 2015). The influx of Southern Europeans was possible due to the generous policy surrounding family sponsorship at the time; this group was able to enter Canada during the years between major shifts in immigration policy that would have otherwise restricted entry due to their ethnicity and socioeconomic status (Aguiar, 2003). The concern for the chain migration that the broad inclusion criteria of "family" allowed led to an immigration policy in which "one Italian immigrant meant forty-nine Italian relatives" (Hawkins, 1972). This led to a significant change in the ethnic make-up of Canadian society and therefore, the definition of "family" needed to shift in order to attain the image that policy makers had for the future of Canada.

This shift led to the exclusion of "distant relatives" in the definition of family; aunts, uncles, nieces, nephews and adult siblings were considered "non-dependents" and were therefore no longer eligible for family sponsorship. This shift highlights the influence of race and 
socioeconomic status in the concept of "family" and the notion of "dependency." This perception is understood through a colonial lens and is described by the 1974 Green Paper on Immigration that summarized the sentiments towards family reunification in immigration policy as a "duty to accept those close relatives who would normally be dependent on them in a society such as our own” (Department of Manpower and Immigration 1974). As mentioned previously, this concept indicated that, in Canadian society, aunts, nieces, nephews and adult siblings were no longer considered part of the "family" and were therefore subject to the same skill and educational requirements as non-sponsored immigrants (Chen, 2015).

There is also a discrepancy that exists in family reunification policies which suggests that the opportunity to sponsor a family member and thus be reunited with family in one country is a privilege, not a right. This ideology is evident in a 1995 publication from the Department of Citizenship and Immigration which outlined that

When Canadian citizens or permanent residents sponsor family members to immigrate to Canada, they undertake an important responsibility. A sponsored immigrant is permitted to come to Canada because of the family relationship and the sponsor's commitment to support that immigrant. Sponsorship is a privilege, and sponsors have an obligation to look after their families once they arrive here (Citizenship and Immigration Canada, 1995).

While family reunification may not be solidified in policy as a right, it is understood that the concept of family as a unit should be protected, such principles are identified in the Universal Declaration of Human Rights of 1948, which states that the "family is the natural and fundamental group unit of society and is entitled to protection by society and the state" (DeShaw, 
2006, p.9). While this was initially respected in the 1976 Immigration Act, the restrictions to family sponsorship in the 1970's and up until more recent policy shifts reflect a perception of parents and grandparents as a burden on Canadian society. This is evident in a government publication that outlined "sponsorship is a privilege, and sponsors have an obligation to look after their families once they arrive here" (DeShaw, 2006). Such descriptions highlight a shift in the value of family reunification from the 1990's onwards, as economic prioritization began to grow. A review of the shifts in family sponsorship policies indicates the notion of "family" and its inclusion criteria as a flexible concept that is dependent upon the economic interests of the state, as opposed to a fixed construct connected to the importance of reunification.

\subsection{The Value of Parents and Grandparents}

While the current Liberal government increased the application quota for the PGP sponsorship program, the dominant discourse surrounding family reunification confronts the widely held view of family sponsorship as a program that does not provide an economic contribution to the labour market (Bragg \& Wong, 2016). This view indicates an undervaluation of the support that family networks provide as social capital during the settlement and integration process in a new country; it also fails to acknowledge the connection between social capital and the overall success of immigrants in the labour market (Bragg \& Wong, 2016).

This connection is prevalent throughout the relevant literature, which explores how sponsored family members contribute to the "economic well-being" of the household through their labour contribution in the private sphere, such as child care, which then allows other members of the family to participate in the public sphere labour market (VanderPlatt, M., Ramos, H. \& Yoshida, Y., 2012). Bragg and Wong also confront the idea of immigrant families 
as "non-contributing members" of society by emphasizing the inability of human-capital theory to capture the importance of labour in the private sphere. Such labour includes the emotional and social upbringing that is primarily done in the home; this work isn't considered to have a direct link to the economy, leading to its undervaluation in immigration policy.

However, the literature highlights the many economic and non-economic contributions to Canadian society that parents and grandparents make (VanderPlatt, M., Ramos, H. \& Yoshida, Y., 2012). Many parents and grandparents that enter Canada through the PGP Sponsorship Program are younger than many argue and make financial contributions to their family by providing childcare or working outside the home (VanderPlatt, M., Ramos, H. \& Yoshida, Y., 2012). Such financial contributions are in addition to the many social and cultural benefits that parents and grandparents provide through knowledge sharing and socialization (Neborak, 2013). However, it has become increasingly evident that in order for the PGP Sponsorship program to survive in Canadian immigration policy, there must be a direct link to the economy.

\subsection{Neoliberal Shifts in Family Reunification \& the PGP Sponsorship Program}

Throughout the literature, there is a clear emphasis on the neoliberal shifts in family reunification policies and their impact on immigrant families. This section will identify the policy changes that reflected a prioritization of the economic value of immigrants as opposed to acknowledging and addressing the issue of family reunification through immigration policy.

One of the most significant modifications is observed in the ratio change of the immigration categories and its impact on family reunification, especially the sponsorship of parents and grandparents. The shift in prioritization from the family reunification and humanitarian categories to, instead, the economic category was indicative of the prevalent 
neoliberal ideology and the value it placed upon the solely economic value of immigrants (AratKoc, 1999). While economics had always been prioritized, they had also been balanced; with neoliberalism, this balance began to disappear. In 1992, the Progressive Conservative government introduced amendments to the 1976 Immigration Act with Bill C-86; the amendments represented a shift in immigration priorities that emphasized professional and business class immigrants (Arat-Koc, 1999, p.42). This emphasis was continued by the Liberal government which, in 1994, conducted a public consultation during a time of economic recession and in a climate of negative public attitudes towards immigrants and refugees (Arat-Koc, 1999, p.42). This consultation, therefore, highlighted the anti-immigrant rhetoric in society and led to an immigration strategy which would "ensure that newcomers to Canada can integrate and contribute to Canada as quickly as possible, without adding to the burden on social programs" (Arat-Koc, 1999, p.43).

The ratio of humanitarian class immigrants to economic class immigrants or, in other words, the ratio of those that came through family reunification and refugee programs compared to those that met certain economic criteria went from 60:40 to the reverse (Bragg \& Wong, p. 46), signifying a noticeable transition. This imbalance was also reflected in the fact that family class immigrants dropped as low as 22 percent in 2012 (Bragg \& Wong, p. 46).

Figure 1 reflects the shifts in the admission category of immigrants in Canada from 1980 to 2016. It is evident that from 1980 until 1994; both the family reunification class and the economic class of immigrants experienced increases and decreases in admission numbers. However, since 1994, the prioritization towards economic class immigrants is clear as the admission rates continued to increase as immigrants sponsored by family members decreased drastically. 
Figure 1: Admission categories by year of immigration, Canada, 1980 to 2016

Distribution (in percentage) of admission categories by year of immigration, Canada, 1980 to 2016

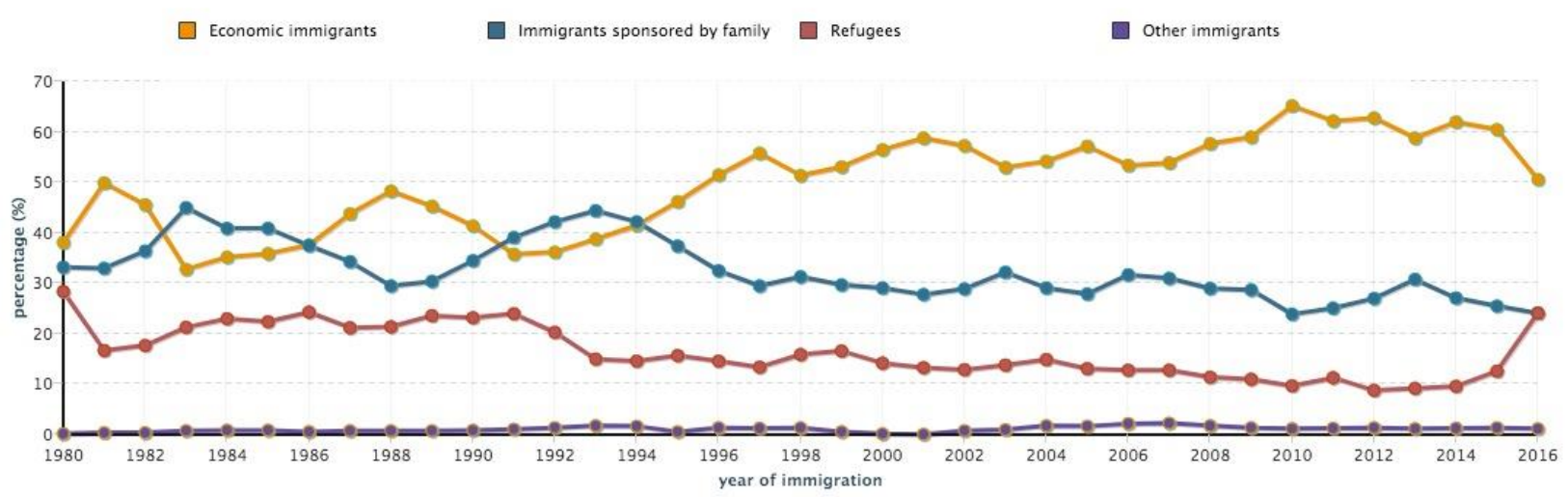

Statistics Canada, Census of Population, 2016

While it is important to recognize that economic immigrants could bring their nuclear families with them (Arat-Koc, 1999), it must be noted that Canada primarily chose these immigrants based on the economic value they would provide, as opposed to any humanitarian reasons. This change in ratio is compelling because it highlights the growth of economic prioritization and its connection to the public sphere of the labour market at the expense of the social commitment to reunite family members in Canada.

Figure 3: Family Class Immigration, 2005-2010

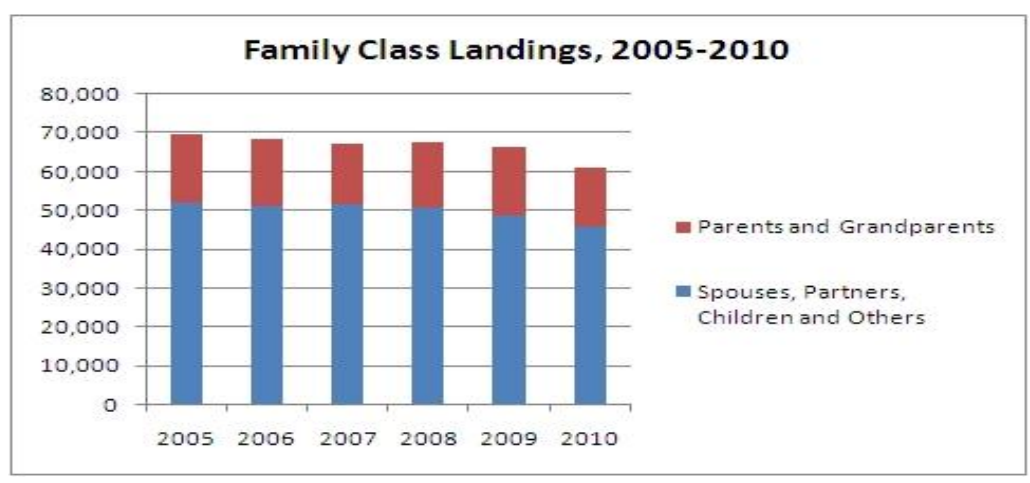

Canadian Council for Refugees, 2011

Figure 2 further demonstrates the shift experienced by parents and grandparents within the family class admissions from 2005-2010. While the total number of new PR's had increased during this time; there were fewer family class member landings in 2010 than in 2005 and PGP 
applicants represented one quarter of the total applicants within the family class (Canadian Council for Refugees, 2011).

Furthermore, this neglect of the importance and value of family in settlement and integration continued with the temporary closure of the family reunification program altogether in 2011(Bragg \& Wong, 2016, p. 47). Although this closure was claimed to be offset by a new policy, called the "Parent and Grandparent Super Visa," the strict requirements, conditions and limitations of this visa were no substitute for the importance of the family class program to immigrant women (Bragg \& Wong, 2016, p. 47).

The family class and new "Super Visa" were important parts of supporting the private sphere since they helped to create a pathway in which a stronger social network could contribute to childcare and domestic support, which were key factors in helping immigrant women succeed and integrate into Canadian society. Having support in the private sphere opened up the opportunity for immigrant women to seek employment, it also offset the high cost of childcare by having family to support with this (Bragg \& Wong, 2016, p. 53). However, as has been continuously discussed, the private sphere was of no importance in a neoliberal society and, therefore, the ability of immigrants to sponsor family and grandparents was not a major concern. This lack of concern is highlighted through the inaccessibility of the "Super Visa" for many immigrant families. In addition to the cost associated with visas, the "Super Visa" also required families to meet a minimum income and purchase Canadian medical insurance (Bragg \& Wong, 2016, p. 47). These strict requirements meant that only those with a certain economic background were able to sponsor relatives and, even then, the visa could only be renewed for up to 10 years, leaving families with no alternative after this time (Bragg \& Wong, 2016, p. 47). Throughout all of this, there is a clear transfer of support from what the state had previously 
provided now becoming the responsibility of the individual in the ongoing emphasis of "selfreliance" in neoliberalism.

The restrictions of the PGP and the inaccessibility of the application form are covered throughout the literature, most recently in the interviews conducted in Beth Martin's 2017 dissertation. Martin highlights the strict eligibility requirements for sponsorship, requirements that prioritize financial factors, such as income level, as the key determinants of an individual's ability to support and sponsor a family member. Martin also explores the requirements postsponsorship that outline the number of years an applicant must be financially responsible for their family member. This financial requirement emphasizes a common theme throughout the literature, which labels sponsored family members, particularly older ones, as a "burden" and, therefore, a responsibility that should remain within the private sphere (Bragg \& Wong, 2016). Following the restrictions of the 1990's, major policy changes arose in 2013 with the Conservative government in power. Once again, the changes reflected a concern for the economic impact of sponsored parents and grandparents; this impact can be analyzed through a neoliberal lens that demonstrates the value of human-capital theory in immigration policy. These changes included a $30 \%$ increase in the minimum necessary income (MNI) required to sponsor a parent or grandparent, the need to provide proof that the applicant could meet the MNI for three consecutive years, as opposed to the previous requirement of one year, and an extension of the commitment period of financial responsibility for sponsored parents and grandparents from 10 years to 20 years (Neborak, 2013). Such changes show an increased concern for the economic burden that parents and grandparents may impose on Canadian society and, therefore, a clear objective to place this responsibility on the sponsor. These changes do not indicate a concern for the reunification of families, as parents and grandparents are only eligible to enter Canada if the 
government is not required to support them. The changes demonstrate further restrictions as interested applicants are required to use Canada Revenue Agency (CRA) notices of assessment as their proof of income stability (Neborak, 2013). The 20-year commitment period meant that sponsors would be responsible for repaying any social assistance benefits for 20 years, thereby alleviating the government of any responsibility to support sponsored parents or grandparents (Neborak, 2013).

Figure 4: Top source regions for family-class immigration to Canada

\begin{tabular}{lrrrrrr} 
Country & $\mathbf{1 9 9 6}$ & $\mathbf{1 9 9 7}$ & $\mathbf{1 9 9 8}$ & $\mathbf{1 9 9 9}$ & $\mathbf{2 0 0 0}$ & $\mathbf{2 0 0 1}$ \\
\hline India & 13,496 & 11,190 & 9,969 & 9,534 & 12,007 & 12,627 \\
China & 4,265 & 4,935 & 5,059 & 5,560 & 5,743 & 6,472 \\
Hong Kong & 5,296 & 3,985 & 1,795 & 1,058 & 1,182 & 898 \\
Philippines & 4,958 & 3,742 & 3,254 & 4,031 & 3,381 & 3,395 \\
United States & 3,163 & 2,497 & 2,600 & 2,948 & 3,167 & 3,601 \\
& & & & & & \\
\hline
\end{tabular}

SOURCE: CIC (1998, 1999, 2000)

It is also important to consider the types of individuals who were most affected by the changes the PGP Sponsorship Program. As Figure 3 shows, the main source regions for family class immigrants during the major changes of the Liberal Party's 1995-2000 immigration plan were India, China, Hong Kong and the Philippines. This trend has continued; in 2013, India, China and the Philippines accounted for 55.7 percent of family class immigrants (Chen, 2015). This is significant because it indicates that restrictions to the PGP Sponsorship Program affect Canadian families of the Asia-Pacific region most. The main source regions and ethnicities of the PGP Sponsorship Program are important to consider when analyzing the xenophobia that the Liberal government was responding to with their 1995-2000 immigration plan which clearly outlined the characteristics of a "good immigrant" as one that could "integrate and contribute to Canada as quickly as possible, without adding to the burden on social programs" (Chen, 2015). 
The neoliberal policy shifts since the 1990's demonstrate a clear shift in perception of the value of parents and grandparents in immigration policy in comparison to the 1976 Immigration Act. The restrictions highlighted above reflect an increasingly inaccessible family reunification program and clearly highlight family reunification as a privilege for those of a certain socioeconomic status, as opposed to a commitment from the government, as it had previously declared in the 1970's. The 2012-2013 policy changes further represent a growing concern for the economic cost of parents and grandparents and, therefore, a clear indication of economic output as not only the primary purpose for immigration, but also, increasingly the only purpose for immigration. The restrictions reflect a trend in family reunification in Canadian immigration policy, a trend of policy makers shifting the concept and purpose of family sponsorship in accordance with the interests of the state.

\section{CHAPTER 5: CRITICAL ANALYSIS}

\subsection{Policy Changes and the 2019 PGP Sponsorship Application Process}

The 2018 PGP Sponsorship Program and the system used for its application process is helpful in understanding the current controversy surrounding the recent experience with the 2019 PGP application process. It demonstrates continuity in the neoliberal ideology guiding immigration policy and also clearly exposes a theme in immigration policy of continually implementing, and switching between, flawed systems that are inadequate in addressing the core issues in family sponsorship policies. As the literature highlights, the core issue in the sponsorship experience is an undervaluation of parents and grandparents and the failure to acknowledge the importance of family reunification for the well-being of Canadian society. This 
section will incorporate an analysis of news releases, government statements and media coverage to analyze and compare the 2018 and 2019 PGP application processes.

The 2018 PGP Sponsorship Program used a lottery system for its online application process; this lottery system was originally implemented as the Liberal government's attempt to make the system "more fair and transparent" (Tunney, 2018). The lottery system required interested sponsors to complete an online form within a 30-day window; at the end of the application window, IRCC randomly selected 10,000 sponsors from the pool of applicants (Harris, 2016). These 10,000 individuals were then invited to complete a full application for the PGP Sponsorship Program and those who were not selected could try again the following year. With 95,000 applications submitted in the 2018 pool; this meant that around one in ten interested sponsors were selected to move on to the next phase of the application process (Harris, 2017). Interested applicants expressed their frustration with a system considered "unjust," with a "methodology gambling with the lives of hard-working Canadians trying to unite with their loved ones" (Harris, 2017).

The change to a lottery-based system was in response to previous criticisms that the 2016 PGP Sponsorship process did not provide an equal opportunity to all applicants since it was based on a first-come, first-served process (Harris, 2018). A first-come, first-served system was criticized as unfair due to the advantage it granted those with the financial resources to access legal support and representation during the application process (Harris, 2018). The 2018 system's shift to a lottery-based system indicated the government's attempt to address some of the criticism surrounding a first-come, first-served however, the way in which it was rolled out meant that those who had previously been in queue for sponsorship were then included in a 
random lottery with all other applicants (Harris, 2018). The 2016-2018 experience with the PGP Sponsorship Program highlighted the limitations and issues associated with both a lottery and a first-come, first-served system for submitting applications.

The Liberal government addressed some of the criticisms of the 2018 experience with the PGP Sponsorship Program by increasing the quota of sponsored parents and grandparents from 17,000 in 2018 to a total of 20,000 in 2019 (Keung, 2019). However, this increase did not address the fundamental issue of the role that neoliberal and human-capital ideologies played in guiding the eligibility requirements and restrictive application process that favoured those with certain skills and education (Martin, 2017). The Liberal government returned to a first-comefirst-served online application system in 2019 due to criticisms that the lottery system, and the possibility of reuniting with family members in Canada, was "based on luck" (Tunney, 2018). The shift to a first-come, first-served application process was announced in a news release from IRCC on January $11^{\text {th }}, 2019$; it read as follows:

The launch of the 2019 PGP Program will include a new and improved intake process. The Government of Canada has listened to and addressed concerns from clients and stakeholders about the previous intake process and has taken steps to provide a first-in-first-served approach for 2019. This approach will further enhance the client experience by keeping the application process fair for all, while remaining an easy-to-access electronic method for applicants.

The news release posits that the government had created a policy that addressed concerns from the public; such concerns revolved around fraudulent, ineligible or duplicate applications that had been accepted into the pool over legitimate ones (Harris, 2019). The government's 
changes to the application process included a requirement for interested applicants to upload a copy of their status in Canada document when submitting their ITS form (IRCC, 2019). The Department also acknowledged the issue of duplicate or potentially fraudulent submissions through the introduction of electronic features that could help detect such issues however, it did not specifically outline what these features were or how they would assess submissions.

The return to a first-come, first-served system meant that interested applicants would be required to fill out an ITS form when the application went live on IRCC's website on January $28^{\text {th }}, 2019$. The ITS form was the first step in the application process; it was a form to express interest in sponsoring a parent or grandparent abroad and to prove that the applicant had met the eligibility requirements to sponsor and support their family member. IRCC announced that once 27,000 ITS forms were received, that the application window would close. IRCC received 27,000 ITS forms within 11 minutes of the form going live, meaning that many interested applicants did not have the opportunity to submit their form for sponsorship. Once duplicates and illegitimate applications were removed from this pool of 27,000 ITS forms, invitations were sent out to the first 20,000 applicants of the group, who were then notified that they would have the opportunity to submit a full application for the PGP Sponsorship Program. This meant that of the 100,000 individuals who accessed the ITS form when it went live, only 27,000 applicants were able to submit the forms; from here, only 20,000 applicants were then invited to complete and submit a full application for sponsorship.

As was the case in 2017 and 2018, a change in application systems did not address the core issues with the application process and instead further emphasized a neoliberal ideology by providing an advantage to sponsors of a certain socioeconomic group. The first-come, first- 
served application process experienced similar criticisms to that of the 2017 process; it was considered to be discriminatory due to the financial and educational factors that would make an applicant more successful, thus producing a system that was not equitable.

The 2019 PGP application process reflects the influence of human-capital theory in immigration policy; many applicants expressed a concern for the variety of factors that advantaged certain groups, such as their access to the internet, typing skills, English language skills, and the ability to take time away from work in order to fill out the application (Tunney, 2018). Such characteristics meant that only those with certain skills would have a chance of successfully submitting an "Interest to Sponsor" (ITS) form, which is the first step in the process for family sponsorship. Immigration lawyers, Clifford McCarten and Will Tao, both highlighted the important role that English and French language skills, as well as typing skills, played in the application process (The Canadian Press, 2019). As Tao explained "there are individuals who, frankly, never were offered an equal opportunity to access this form or this process" (The Canadian Press, 2019); such sentiments highlight the inequality inherent in the system. As mentioned previously, the ITS application form closed in just 11 minutes, highlighting the critical component that timing and the ability to fill out a form quickly, played in an applicant's opportunity to sponsor a family member abroad.

The criticisms of the 2019 application process reflect the same criticisms of the previous first-come, first-served process of 2016, signifying that changes to the application process were not an effective way to address the backlog and wait times surrounding the PGP Sponsorship Program. The media coverage surrounding the 2019 application experience also highlights the expansion of human capital characteristics, not only in immigration policy, but in the application 
process itself. The government announced that it would continue to re-evaluate the concerns surrounding the 2019 PGP Sponsorship Program (Harris, 2019) however, as the recent history of policy changes demonstrates; such issues are directly related to the prioritization of the labour market in immigration policy and the perception of elderly immigrants as a strain on Canadian society, as opposed to the system used for the application process.

\section{CHAPTER 6: DISCUSSION}

It is evident that the current application process for the PGP Sponsorship Program fails to provide an equal opportunity to those wishing to sponsor family members abroad. Throughout the shifts in policy, the government has been unable to identify an equitable approach to family reunification because the concept of family itself has not been viewed equitably by policy makers. While family sponsorship is described as a core component of Canada's immigration policy (Harris, 2018), and has always had a place in Canadian immigration history; its true value is reflected in the shifting policies since the 1990's and the restrictions imposed on families up until the most recent application process.

By placing the most recent experience in the historical context of family sponsorship in immigration policy, it is evident that there is a continuity in the ideologies from the 1990's and that the influence of neoliberalism and human-capital theory have expanded from the policy itself into the application process. The growing influence of neoliberalism in the application process itself is emphasized through a system which rewards those with the human capital, such as, typing skills, education and knowledge when determining the success of an individual's application. As highlighted throughout available content, interested applicants would need to 
have certain skills and the ability to navigate an online process in order to simply fill out the ITS form.

IRCC's news release described the 2019 process as "easy-to-access electronic method for applicants;" such wording not only assumes that an online method is easy for everyone to use, it also assumes that all interested applicants can easily access a computer and a reliable Internet connection. This "easy-to-use" method was also criticized by participants who experienced technological glitches with the process and were never able to access the form before the 11minute application window closed (The Canadian Press, 2019). An analysis of the media coverage surrounding the 2019 policy reflects a connection between certain skills and education and success in the application process. This connection is in line with the historical influence of human-capital theory in immigration policy and further disadvantages the most vulnerable individuals who may face physical and financial barriers throughout the application process and, thus, are not granted the opportunity to participate in the first, and necessary, stage of the sponsorship process.

However, even with the skills and financial resources required to submit an ITS form, the 27,000 applicated spots filled within minutes, signifying a greater issue within the sponsorship policy for parents and grandparents. A critical analysis of the 2019 PGP sponsorship process demonstrates the continuation of failed policies and inequitable application systems. It is clear that the amendments to the application system over the past three years are not working. The continual shifts between a lottery and first-come, first-served system in the application process indicate that the issues surrounding the inaccessibility of the PGP Sponsorship Program cannot be addressed solely through a change in online systems. The administrative delays and wait 
times in the PGP Sponsorship Program are not a result of too many applicants accessing the program, but are, instead a reflection of how policy makers value parents and grandparents. The ideology guiding the policy is not rooted in an acknowledgement of the value and contributions of parents and grandparents, but instead, in the economic burden of parents and grandparents may present. While the government describes the continuation of criticisms surrounding the PGP Sponsorship Program as an issue of "too many interested applicants" (Harris, 2019); a deeper analysis of the history of family sponsorship and its policy changes has highlighted more complex issues than merely one of numbers (Chen, 2015).

The Minister of Immigration, Refugees and Citizenship expressed that "family reunification supports Canada's economic prosperity and further strengthens communities" (IRCC, 2019). While the current government acknowledges that "parents and grandparents often help care for children and make meaningful contributions to their communities," such appreciation is not reflected in the undervaluation of parents and grandparents in comparison to economic class immigrants. The government announced that consistently higher admission levels for parents and grandparents had addressed the issue of the application backlogs; this was demonstrated by a decrease from 167,000 applications in 2011 to 28,000 in 2018 (IRCC, 2019). It is clear that increasing admission levels for parents and grandparents is a core component of addressing wait times and backlogs; if the government truly acknowledges the contributions that parents and grandparents make, then this increase must continue.

\section{CHAPTER 7: CONCLUSION AND IMPLICATIONS}

The sponsorship of parents and grandparents in immigration policy has continually faced criticism and controversy due to a backlog in applications and an inequitable process; both of 
which reflect how the government values family reunification, as well as the growing influence of neoliberal ideologies in immigration policy. By analyzing the literature available regarding the 2019 PGP Sponsorship Program application process, this study provides a greater understanding of the current status of family reunification, specifically parents and grandparents, in Canadian immigration policy.

Family reunification is a priority for immigrant families; this is evident in the literature and is reflected by the 100,000 individuals that attempted to access the most recent ITS form on January $28^{\text {th }}, 2019$ (IRCC, 2019). The limited availability meant that 73,000 interested individuals did not have the opportunity to move forward in the application process, and far more did not meet the requirements for eligibility.

This study highlights the importance of family reunification and the ineffectiveness of the recent immigration policies in addressing this issue. It also demonstrates a trend in Canadian immigration policy to shift terms and values dependent upon the governing bodies needs at the time. Such needs have increasingly prioritized the economic output of immigrants, especially in regard to the sponsorship of parents and grandparents. An analysis of the 2019 PGP sponsorship process has demonstrated the continuation of failed policies and inequitable application systems. It is clear that future application systems will continue to fail if the ideology guiding the policy is not rooted in family reunification values, but, instead, in the economic contribution of parents and grandparents.

By placing the 2019 PGP Sponsorship Program in the context of the history of family reunification policies in Canada, it is clear that there is a continuation of the ideologies guiding immigration policy and that influence of neoliberalism, human-capital theory and colonialism 
persist. The 2019 PGP application quota increase demonstrates a component of the policy that is working, suggesting that increasingly higher application quotas through a re-evaluation of the value and contributions of parents and grandparents is necessary. The separation of families across borders and the current policy's inability to address this separation is a social issue that is significant to all Canadian citizens and permanent residents. As the literature continually emphasizes, the social capital that the family network provides is a contributing factor to the overall well-being of individuals and their participation in Canadian society and, therefore, it should be appropriately valued in federal immigration policies.

\section{CHAPTER 8: LIMITATIONS}

This MRP aimed to explore the PGP Sponsorship Program and the 2019 application process through the lens of neoliberalism and colonialism however, further research on this topic could utilize ageism as another theoretical background. It is evident that the age of individuals being sponsored in the PGP Program is a primary concern to policymakers; this is reflected in a government statement that expressed:

The average age of a PGP principal applicant at arrival is 65 years. In Canada, more than $50 \%$ of a person's

lifetime health care expenses are incurred after age 65; these consume early $44 \%$ of all health care dollars. ${ }^{1}$

\footnotetext{
${ }^{1}$ Citizenship and Immigration Canada. "Regulations Amending the Immigration and Refugee Protection Regulations.” Regulatory Impact Analysis Statement. Canada Gazette. Vol. 147, No. 20. May 18, 2013. Online http://www.gazette.gc.ca/rp-pr/p1/2013/2013-05-18/html/reg2-eng.html
} 
The discourse surrounding the age of PGP applicants and the burden they may impose upon the healthcare system further emphasizes the notion that parents and grandparents are older and that older individuals will not be as healthy as younger ones. Future research could explore this topic through the lens of ageism and look at the more recent statistics of PGP applicants from 2016 onwards to identify the age range of individuals admitted through the program and to highlight any shifts or trends in this category. 


\section{REFERENCES}

Aguiar, L. (2006) “The New 'In-Between' Peoples: Southern-European Transnationalism” in Vic Satzewich \& Lloyd Wong Transnational Identities and Practices in Canada. UBC Press Vancouver Toronto.

Arat-Koc, S. (1999). Neo-Liberalism, State Restructuring and Immigration: Changes in Canadian Policies in the 1990s. Journal of Canadian Studies, 34(2), 31-56.

Bragg, B. \& Wong, L. (2016). "Cancelled Dreams": Family Reunification and Shifting Canadian Immigration Policy. Journal of Immigrant \& Refugee Studies, 14(1), 46-65.

Chen, X. \& Thorpe S. (2015). Temporary families? The parent and grandparent sponsorship program and the neoliberal regime of immigration governance in Canada. Migration, Mobility \& Displacement, 1(1)

DeShaw, Rell. "The History of Family Reunification in Canada and Current Policy." ProQuest. Canadian Issues: Spring 2006: 9-14.

Harney, N. (1998). Eh, Paesan!: Being Italian in Toronto. Toronto, Ontario: University of Toronto Press.

Harris, K. (2019, January 28). "Online applications to sponsor family immigrants hit limit in less than 11 minutes." Retrieved from https:/www.cbc.ca/news/politics/ircc-parentgrandparent-sponsorship-filled-2019-1.4995806.

Harris, K. (2018, January 7). Retrieved from https://www.cbc.ca/news/politics/immigrationparents-grandparents-sponsorship-1.4442456.

Harris, K. (2016, December 14) Retrieved from https://www.cbc.ca/news/politics/canadaimmigration-parents-grandparents-1.3895808.

Hrvatin, V. (2018). "Lottery for parent sponsorship to be replaced, more applications to be accepted." Retrieved from https://search-proquestcom.ezproxy.lib.ryerson.ca/docview/2090841827?pq-origsite=summon

Immigration Refugees and Citizenship Canada. https://www.canada.ca/en/immigration-refugeescitizenship/services/immigrate-canada/caregivers.html

Immigration Refugees and Citizenship Canada Newsroom. (2019, January 11). "New and improved intake process for sponsorship of parents and grandparents to launch on January 28, 2019.” Retrieved from https://www.canada.ca/en/immigration-refugeescitizenship/news/2019/01/new-and-improved-intake-process-for-sponsorship-of-parentsand-grandparents-to-launch-on-january-28-2019.html 
Keung, N. (2019, January 28). "Frustration builds as 27,000 spots to sponsor parents, grandparents snapped up in minutes." Retrieved from https://www.thestar.com/news/canada/2019/01/28/frustration-abounds-as-27000-spots-tosponsor-parents-grandparents-snapped-up-in-minutes.html

Martin, B. (2017). ""A Stone in the Ocean": A Mixed Methods Investigation into the Experience of Families Trying to Reunite in Canada.' Ryerson University.

Neborak, J. (2013). "Family Reunification? A Critical Analysis of Citizenship and Immigration Canada's 2013 Reforms To The Family Class." Theses and dissertations. Paper 2060. Ryerson University.

Roberts, D. \& Mandani, M. 'Neoliberalizing Race, Racing Neoliberalism: Placing "Race" in Neoliberal Discourses’ (pp. 248-257) Antipode, 42: 2, 2010.

Siemiatycki, Myer. (2015). Continuity and change in Canadian immigration policy. In H. Bauder \& J. Shields (Eds.), Immigrant Experiences in North America: Understanding Settlement and Integration. (pp.93-117). Toronto: Canadian Scholars Press

Telegdi, A. (2006). Family Reunification: The Key to Successful Integration. Canadian Issues, 94-96. Retrieved from http://ezproxy.lib.ryerson.ca/login?url=https://searchproquest-com.ezproxy.lib.ryerson.ca/docview/208675838?accountid=13631

The Canadian Press (2019, January 29). "Lawyers slam 'discriminatory' online application for immigrants looking to sponsor family." Retrieved from https://globalnews.ca/news/4904039/immigrant-family-sponsorship-applicationdiscriminatory/

VanderPlatt, M., Ramos, H. \& Yoshida, Y. (2012). "What do Sponsored Parents and Grandparents Contribute?"

Von Scheel, E. \& Dyer, E. (2019, January 2). "Immigration Canada Preparing to Launch Revamped Family Reunification System.” Retrieved from https://www.cbc.ca/news/politics/immigration-canada-family-reunification-1.4963900 